locality ; while th 3 rock has a tendency to lamination, its disintegrated felspathic constituents whiten the whole surface, and the neighbouring hill-slopes overlooking the springs are as white as any chalk-cliffs from the same cause. This phenomenon is only to be found in the immediate vicinity of the hot springs.

It is with the hope that these few notes may be the means of eliciting further particulars, especially as regards the history of this so called volcano of Unzen, that I venture to send them to Nature.

H.M.S. Hornel, Nagasaki,

H. B. GUPPY,

October 13

\section{Astronomical Subject-Index}

I AM preparing for publication, by the Royal Dublin Society, a review of the progress of astronomy during the present year, consisting of a classified index catalogue of books, memoirs, and notes on astronomical subjects published since the beginning of the year, and, secondly, of a short account of the contents of the more important papers in the various branches of astronomy.

Any person who has felt the want of such a "subject index" could assist materially in the undertaking by sending me, as soon as possible, the titles of such papers as seem likely to be overlooked on account of having been published in less widelydiffused periodicals or transactions. In particular I would be glad to hear of papers published quite recently in transactions or proceedings of learned societies, as these often are not dis. tributed until some time after their publication.

J. L. E. DREYer

The Observatory, Dunsink, Co. Dublin, December I I

\section{Distinguishing Lights for Lighthouses}

A propos of your article on Sir William Thomson's letter in the Times, and the dangers to ships from bad systems of distinguishing the lights of different lighthouses, I send you the accompanying graphic account by my brother, Mr. J. P. Thomp son, of a narrow escape from shipwreck which occurred to him during the autumn of the present year, and which illustrates the urgent need for reform in the adopted system.

\section{Silvanus P. Thompson}

"All went well till off Ushant, when the wind began to rise, and by Saturday afternoon the Channel was heaved up by what was logged as a 'moderate gale' from the south-west. This kept freshening every hour, and at 7 P.M., when the lamps were being lit, the captain said we should have a very 'dirty night,' and he accordingly donned his oilskins and 'sou'-wester.' The atmosphere began rapidly to cloud, and at 9 o'clock you couldn't see more than a ship's length or two ahead. As we were in a crowded track of vessels, the watch look-out was doubled. . . . At I I was on deck again, and found all looking out eagerly for either the St. Agnes (Scilly) or the Wolf Light, the latter being near the Cornish coast. Of these lights the St. Agnes shows a white light at each revolution of a minute, whilst the Wolf is the same, but with a flash of red between. The sea was very phosphorescent, and this dazzled the eye when looking for lights. I was set as a look-out on the starboard quarter, and many times had to go aft for the captain to see how she lay by the compass abaft (she was being steered at the wheel in an iron wheel-house on the bridge.) . . . About midnight we sighted a light, and on timing it, found it to be a white light of a minute's revolution; we looked in vain for a red flash between the whites, as we knew we ought to be near the Wolf. But in the fog not a 'smell of red' could be discerned, although by the rate at which we passed it we must have been very near it. Supposing, then, that there was no red flash, this must be the Scilly light, and the captain accurdingly steered more easterly, so as to fetch the Wolf. He nevertheless hardly thought we had got so far to the west as the Scilly, so he ordered a sharp look-out to be kept for breakers or land. At 3.30 I turned in again, but at 4 A.M. I suddenly heard the lookout cry out 'Land! breakers ahead!' and then I heard the captain run to the telegraph, and heard the bell ring in the engine-room, and the captain's sonorous voice calling 'All hands! square away the yards! 'bout ship !' I jumped up, and ran on deck, and there right ahead the fog had just lifted to show us we were almost ashore, heading straight on Penzance; so near, indeed, were we that I could have easily counted the houses. Happily the ship, answering her helm well, came round beautifully, and at the same time the fog closed again, hiding the shore and the dreaded rocks. So after all it was the Wolf light we had sighted, but the fog had prevented us from seeing the red flash. It was a narrow escape, though; and then we had to beat back in the teeth of the gale, and it took us six hours to beat back to the Land's End."

\section{The First " Sin"}

IT occurred to me lately, whilst reading in the September number of the Contemporary Review, an article by Lenormand called "The First Sin," that it may be possible to turn another page of that very interesting history of ideas, the reading of which appears to be one of the great tasks allotted to this century. Although it seems nnlikely that the idea sugrested to me by the article has not also occurred to others, I cannot discover that anything has been said about it, for the author seems strangely enough to lead one to the door, as it were, and leave one there without opening it; I should therefore like, if you will permit me, to lay it before your readers, and hear what they have to say about it.

My idea is this : that the tradition of a tree of Iife, and also of a tree of the knowledge of good and evil, both connected with a sin and a catastrophe, probably originated in man's first acquaintance with the effects of intoxication.

Lenormand himself connects that tradition with the worship of Bacchus (and also with the theft of fire in a piece of a tree by Prometheus, and with that of the apples of the Garden of the Hesperides). It seems strange, therefore, that he goes no farther, more especially as he himself points out that the representations of the tree on the monuments of different nations are always referable to those from the fruit or foliage or crushed branches of which an intoxicating liquor is derived; from the Soma tree, that is, and the palm and the vine.

There is no need to burden your pages with proofs and quotations, as any one interested in the subject can procure the magazine now at half price; I will merely add to my suggestion that, as the primitive notion of life must have been characterised by warmth and motion, and the first effects of the fruit of the tree would also be, probably, warmth and excitement, exhilaration and the temporary exaltation of some of the faculties, it would easily come to be looked upon as a "tree of life;" and that, the after-effects being bad and degrading, it would thereby become a tree of the knowledge of evil as well as good, and also the cause of a fall into a lower state of being.

May I add a suggestion concerning the serpent always con nected with the tree, as on the early Babylonian cylinder figured on p. 9I of George Smith's "Chaldean Account of Genesis"? It appears to have represented the principle of evil very early, probably long before it was connected with the tree, and to have been at first the sea, which in a storm was the chaos out of which everything was formed, and which, as it seemed to swallow up sun, moon, and stars, and to bring forth the storm-cloudsthose monsters with which the sun-god fought with his arrows the lightnings-came also, not unnaturally to represent the destructive principle. But how did it become a serpent? May it not have been the singular resemblance that the edge of the sea-as seen from a moderate height in a calm-bears to a huge serpent-now blue, now white, according to the amount of foam - winding and writhing about the earth, and eating out its rocks and shores, that caused its destructive attributes to be transferred to the serpent? A common name may have been the means. The resemblance is especially striking when the eye looks along the shore, as in the bend of a bay.

Another suggestion. Some years ago, when reading the description of the locality of the Battle of Beth Horon in Dean Stanley's work on Palestine, it seemed to me to point to the origin of the tradition of the sun and moon standing still at the command of Joshua, and I do not think it has been noticed. In any valley lying north and suth, if one goes up the western hills as the sun sets to the valley, when one reaches the summit the effect of a new day and a fresh supply of sunlight is very striking. This sensation must have been strongly felt by the warriors of Israel, when, after pursuing their enemies up the pass, the still sunlighted valley beyond broke upon their sight; and I cannot but think that, figuratively expressed, as it would be, and with much exaggeration, in the triumphal song sure to have been made and sung after the victory, it may well have originated the tradition of a standing still of the sun; the moon would follow suit. The songs are said to be the oldest parts of the Bible, and "Jasher" or "The Upright" may have been the singer or recorder of the lost song of triumph. 